\title{
A Cognitive Study of “Anger” Metaphors in English and Chinese Idioms
}

\author{
Peilei Chen \\ Foreign Language School, Henan University of Technology \\ Zhengzhou 450052, Henan, China \\ E-mail: englishplay@sina.com
}

\begin{abstract}
Anger is one of the basic human emotions. This paper takes the metaphorical expressions of "anger" in English and Chinese idioms as the objects of research. The effort is made to find the differences and similarities between English and Chinese metaphorical systems of emotional concepts and the causes of these differences and similarities so as to help people further understand the nature of emotional metaphors.
\end{abstract}

Keywords: Cognition, Anger, Metaphor, English, Chinese, Idioms

Metaphor is a panhuman capability to cognize the world. Every language in the world has similar root metaphors based on common human experience, which actually bear universality in concept. Cognition of new concepts through novel metaphor shows that human beings get to know new things through those root metaphors. When a particular metaphor is said to be universal, it is likely that it is universal conceptually rather than linguistically. Particular instantiation of that conceptual metaphor may still vary because specific cultural models in different languages may indicate different choices of linguistic realization. Metaphors of emotions in the language are most typical examples to show how abstract concepts are structured by more concrete concepts metaphorically, for emotions are highly unstructured concepts. Idioms of "anger" in English and Chinese are good examples to prove that there are same metaphorical concepts of emotions in English and Chinese languages, and on the other hand, metaphors are greatly nation-specific and culture-loaded.

\section{Similarities of "Anger" Metaphors in English and Chinese Idioms}

Anger is another basic human emotion. According to psychologists, when an individual's wish is not met, and the behavior to fulfill this wish is frustrated again and again, stress accumulates and the emotional experience of anger is produced. When the individual knows the source of frustration, people or things, he will normally show angry reactions toward it.

\subsection{ANGER IS HEAT}

In the view of Lakoff (1980) and Kovecses (1986), one basic physiological effect of anger is increased body heat. Given the general metonymic principle that the physiological effects of an emotion stand for the emotion, we get a typical conceptual metaphor in English to express anger: ANGER IS HEAT. It has two versions: one is ANGER IS FIRE, the other is ANGER IS HOT FLUID IN A CONTAINER. The metaphorical concept ANGER IS FIRE is present in both English and Chinese. In English we can find it in the following idioms: add fuel to the fire, to blaze up, to blaze out, hot under the collar to flash/shoot fire.

The Chinese equivalent for anger is 发火 or 恼火. In Chinese we also have such expressions: 怒火中烧，火冒 三丈，七窍生烟.

\subsection{ANGER IS PSYSIOLOGY REACTION}

Another conceptual metaphor is ANGER IS THE PSYSIOLOGY REACTION OF ANGER in English and Chinese idioms. They share something in common in the respect of parts of human body when conveying anger. These shared parts are eyes, hair, face, and hands:

Eyes: to look daggers at someone, to throw one's eyes up, 怒目而视 (to stare at somebody in anger), 横眉怒目 (straightened eyebrows and irritated eyes) and 目光如炬 (one's eyes flash fire as a torch).

Hair: to get in somebody's hair, to lose one's hair, 令人发指 (to make one's hair stand up in great anger) and 怒 发冲冠 to be so angry that one's hackles rise; to bristle with fury). 
Face: to look black, as black as sin / thunder to turn red in the face, 勃然大怒, 勃然变色 (to burst into anger; to fly into a rage), 疾颜厉色 (with sudden outpouring and fierce looks; with hasty words and a stern countenance), 怒形于色 (to show anger on one's face; with an angry look ) and 怫然作色 (to take a distorted look out of anger).

Hands: to grab for altitude, to shake one's fist at somebody 拍案而起 (to slap the table and rise at a sudden), 拂袖而去 (to flick the sleeves and go away), 戟指怒目(pointing and staring at somebody).

ANGER IS FIRE and ANGER IS THE PHYSIOLOGY REACTON OF ANGER come from the same physical structures and the same physiology reactions of human beings when they are angry. In the metaphorical mechanism, emotional changes can be reflected through physiology reactions of emotions. When one person is angry, his body becomes hot, then his face and head, then the pressure in his body becomes higher to make his vessels swell, then there are some other body reactions such as quivering, clenching teeth, stamping feet, etc; at last his sense organs are affected, such as 两眼发黑, 头昏眼花 etc. So we have the similar expressions in both languages.

\subsection{ANGER IS THUNDER}

ANGER IS THUNDER. An angry person reminds both English and Chinese people of a natural phenomenon--thunder, as they are equally alerting and threatening. In English idioms they describe a man in anger as black as thunder, with a face like thunder; and in Chinese we say 大发雷霆 (to burst into a rage; an explosion of rage), 暴跳如雷 (to stamp with rage; to stamp about in a frenzy), 雷霆之怒 (as powerful as a thunderbolt).

\section{Differences between "Anger" Metaphors in English and Chinese Idioms}

\subsection{ANGER IS SOMETHING HOT IN A CONTAINER}

Both in English and Chinese, anger is compared to something hot in a container. But in the basic English cultural model, anger is more often hot fluid (blood). The English feel something strange with their blood when they are in anger. Their blood may be "up", "hot / warm" and "boiling". We might as well bear it in mind that when an English speaker mentions his blood, you may just keep away from him because that implies he is not in a good mood. (However; in Chinese the conceptual metaphor is BOILING BLOOD IS ENTHUSIASM: when a Chinese feels his blood is hot and boiling (热血沸腾, he is actually fairly emotional and ambitious). Human body is the container of emotions, so ANGER IS HOT FLUID IN A CONTAINER, e.g. (to be) in hot (warm) blood, to make somebody's blood boil. Therefore, anger has every characteristics of heated fluid in a container. One thing we know about hot fluids is that, when they start to boil, the fluid goes upward: one's blood is up, to get (have) one's blood up, to get somebody's blood up. We also know that intense heat produces steam and creates pressure on the container. When the pressure on the container becomes too high, the container explodes. In an explosion, parts of the container go up in the air: to go up in the air, blow one's top, hit the ceiling / roof.

In Chinese the conceptual metaphor ANGER IS HOT AIR IN A CONTAINER is more common, which can be found in idioms:气势汹汹, 怒气冲冲, 杀气腾腾, 肝气郁结, 气冲牛斗, 气急败坏.

These different features stem from the different views of world of two cultures and languages. Stanli, a philosopher in the ancient West, considers water to be the source of the universe. Therefore, it's no wonder that in English anger is compared to fluid in a container. But in traditional Chinese culture, qi (air) is the source of the universe. In Chinese classical philosophy, qi (air) is the basic form of physical existence and the source of life. In the oldest Chinese medical work “黄帝内经”, it is pointed out that all diseases originate from the malfunction of qi (百病生于气也, 怒则气上, 喜则气缓, 悲则气上, 恐则气下，惊则气乱，思则气结......). And the philosopher Wang Chong in the East Han Dynasty said all things in the universe have evolved from qi (天地合 气，万物自生. “论衡·自然”). Qi is so pervasive in Chinese culture and language that we can find various forms of it in idioms and idiomatic expressions: qi signifying weather, e.g.天气睛朗, 秋高气爽; qi signifying destiny, e.g.好运气，气数己尽; qi signifying physical condition, e.g.有气无力, 元气大伤; qi signifying spirit and morale, e.g.勇气可嘉, 血气方刚, 英雄气概, 气派不凡, 暮气沉沉, 喜气洋洋, 卧指气使; qi referring to people's personality and characteristics, e.g.气度非凡, 气量狭小, 脾气暴躁, 气宇轩昂; qi in art and aesthetics, e.g.气韵, 荡气回肠; and qi signifying power and momentum, e.g.气势雄伟, 一鼓作气, 气吞山河 etc.

We can also explain why Chinese language prefers "fire" and "qi (air)" in "anger" metaphors with another important theory in Chinese classical philosophy--Yin Yang theory. According to this theory, all the things in universe are generally divided into two categories: Yin and Yang, which are mutually promoted, restrained and are interchangeable. The qi (air) and fire belong to the category Yang which is related to "hot"; water and other fluids belong to the other category Yin which is related to "cold". So it's easier to understand why the Chinese 
choose fire and qi (air) as the metaphorical concept for anger, while English choose fire and hot fluid, because in English there's no such conceptual system as "qi (air) is the source of the world" nor the metaphorical system about air.

In Chinese anger is hot air and are usually rented to liver and lung, e.g 他肝火很旺. 他肺都气炸了. This is because in traditional Chinese medical science there are such views: anger is harmful to the liver (怒则伤肝); the lung dominate all the air in one’s body (肺主一身之气).

\subsection{ANGER IS HUMAN BODY PARTS}

Apart from idioms related to the shared human body parts mentioned, some idioms can convey wrath only in English or Chinese. In English, people can express anger with ears. An American in anger can not only be put up on his ear or be on his ears, he can even walk off on his ears. In Chinese, besides the eyebrows we have idioms related to the teeth and breast to express anger:

Eyebrows: 柳眉倒坚 (to raise her slender eyebrows in anger), 横眉立目 (to face others with frowning brows and angry eyes), 直眉瞪眼 (to stare in anger).

Teeth: 咬牙切齿 (to clench one's teeth in bitter hatred; to grind one's teeth with anger).

Breast: 义愤填膺 (to be filled with rightful indignation; anger filled one's breast).

Compared with English, Chinese does not express anger with so many human body parts and the movements shown in the idioms are not so dynamic and exaggerative. The eyebrows and vital energy are still of our major interest in idioms to convey emotions. Even when they are angry, Chinese people usually first try to hide their true feelings. Then when they feel rather uncontrollable, they express it on the face, and most possibly, on the brows and eyes. And when the last straw comes, they might take advantage of the limbs. Roughly speaking, Chinese people tend to create idioms to convey anger in some passive way because gentleness and obedience have been regarded as great virtues for thousands of years.

\subsection{ANGER IS AGGRESSIVE ANIMAL BEHAVIOR}

In English idioms we can encounter a conceptual metaphor ANGER IS AGGRESSIVE ANIMAL BEHAVIOR. In the idiom like a bear with a sore head angry persons are compared to bears, which are notoriously bad-tempered. English speakers also molded some idioms from cocks. The hackles are the long feathers on the neck of the domestic cock which rise when it is angry and preparing for a fight. They noticed that the cocks were angry with the hackles up, so they could make someone's hackles rise by ruffling his, feathers. In the idiom to snap (bite) off somebody's head, a person shouting angrily is compared to an animal jumping down a victim's throat. And the idioms to hump one's back and to cross somebody's bows remind us of a fierce beast ready to attack its enemy.

\section{The Cultural Specificity of "Anger" Metaphors in Idioms}

Because of the difference in cultures, emotional metaphors in English and Chinese have respective characteristics. The difference lies in the two peoples' geographic environments, personalities, value, concepts, thinking modes and views of the world, which are reflected in their idioms conveying emotions.

People in the ancient west considered water to be the source of the universe. So in the metaphorical concept ANGER IS HOT FIUID IN A CONTAINER anger is compared to hot liquid. But in traditional Chinese culture, qi (fair) .is the source of the universe and the source of life. So we have the metaphor ANGER IS HOT AIR IN A CONTAINER. Qi is so pervasive in Chinese culture and language that we can find various forms of it in Chinese idioms.

English people are rather frank and direct in manner. To express their emotions, they often apply obvious movements of the whole body or of the four limbs that can be seen from a long distance away. From the different parts of human body or movements applied we may reach a conclusion that English idioms have a tendency towards outwardness. English speakers do not think the liver, the gall and the intestines have anything to do with human's psychology. In any possible cases in which the Chinese might think of other internal parts, they just turn to the heart.

In Chinese traditional culture, modesty, sedation, gentleness and obedience have been regarded as great virtues for thousands of years. So compared with English people, the Chinese people are relatively reserved and tend to suppress their feelings. Much more attention is paid to concrete and inwardness by Chinese people, who tend to express their emotions with movements of rather smaller parts of the body such as eyebrows, inner organs, and even the invisible soul and vital energy. Of course, we also have the actions of beating breast and stamping, but they are not of dominant tendency to be discussed. The Chinese always relate the changes of human moods to 
the five internal organs, i.e. heart, liver, spleen, lungs and kidneys, which have their deep resources from traditional Chinese medical science. Vocal organs are also involved in both English and Chinese idioms, but they appear in different directions.

The England is an island country surrounded by ocean, and life of the British people is closely related to things like boat and water. China is an inland country with agricultural culture. These geographic features are reflected in their idioms.

Images of animals in idioms are also very different in English and Chinese idioms. There is the conceptual metaphor ANGER IS AGGRESSIVE ANIMAL BEHAVIOR in English. An angry person is compared to a bear, a cock or a cat humping its back. The Occidentals used to look on hare or chicken as the synonym of coward, while in Chinese mouse is used to refer to a coward. Though dog appears frequently in English and Chinese idioms, the two peoples have contrary opinions about it. People in the west are very fond of dogs, which are treated as man's best friend and are applied to refer to all kinds of people, while the images of dog often have a derogatory meaning in Chinese idioms.

\section{References}

Dai, Mingzhao. (1996). An Introduction to Cultural Linguistics. Beijing: Language and Literature Press.

Lakoff, G \& M. Johnson. (1980). Metaphors We Live By. Chicago: University of Chicago Press.

Lakoff, G.. (1993). The Contemporary Theory of Metaphor. New York: Cambridge University Press.

Lan, Chun. (2005). A Study of Cognitive Linguistics and Metaphor. Beijing: Foreign Language Teaching and Research Press.

Ning, Yu. (1998). The Contemporary Theory of Metaphor: A Perspective from Chinese. Amsterdam/Philadelphia: John Benjamin's Publishing Company.

Ye, Yiqian. (1991). General Psychology. Shanghai: East China Normal University Press. 